\title{
A fala dos corpos. Entre Cixous, Shelley e Queizán
}

\author{
Body Speech and Cixous, Shelley and Queizán
}

\author{
Elvira FENTE \\ Université Paris VIII \\ elvirafente@gmail.com
}

[recibido 06/10/2014, aceptado 26/01/2015]

\section{RESUMO}

Pretendemos amosar as analoxías existentes entre as obras de Hélène Cixous, Mary Shelley e o pensamento feminista de María Xosé Queizán. Trataremos o significado de corpo das mulleres e como Cixous e Queizán o identifican coa palabra. Analizaremos como Queizán se inspira a partir do traballo de Mary Shelley, concretamente de Frankenstein, para entender a maternidade. Cando os corpos reprodutores sexan substituídos por máquinas lograrase, di Queizán, a verdadeira igualdade.

PALABRas CHAVE: Queizán, Shelley, Cixous, corpo, muller.

\section{RESUMEN}

Pretendemos mostrar las analogías existentes entre las obras de Hélène Cixous, Mary Shelley y el pensamiento feminista de María Xosé Queizán. Trataremos el significado de cuerpo de las mujeres y cómo Cixous y Queizán lo identifican con la palabra. Analizaremos cómo Queizán se inspira a partir del trabajo de Mary Shelley, concretamente de Frankenstein, para entender la maternidad. Cuando los cuerpos reproductores sean sustituidos por máquinas se logrará, dice Queizán, la verdadera igualdad.

PALABRAS CLAVE: Queizán, Shelley, Cixous, cuerpo, mujer.

\section{ABSTRACT}

We aim to display the analogies between the work of Hélène Cixous, Mary Shelley and feminist thought of María Xosé Queizán. We will try to understand the meaning of woman's body and how Cixous and Queizán identify it with the word. We will see how Queizán is inspired by Mary Shelley's work, Frankenstein specifically, to understand motherhood. When the reproducers bodies will be replaced by machines we will achieve, says Queizán, the true equality.

KEY WORDS: Queizán, Shelley, Cixous, body, woman.

Fente, E. (2015): “A fala dos corpos. Entre Cixous, Shelley e Queizán”, Madrygal (Madr.), 18, Núm. Especial: 337348.

SUMARIO: 1. Introdución. 2. O corpo toma a palabra. 3. Mulleres ou corpo reprodutor? 4. Conclusións. 5. Referencias bibliográficas. 


\section{INTRODUCIÓN}

Existen analoxías entre as obras de Hélène Cixous, Mary Shelley e o pensamento feminista de María Xosé Queizán. O significado de corpo das mulleres para Cixous e Queizán mestúrase coa palabra en ambas as dúas autoras. As orixes da escrita feminina atópanse na procura da feminidade e na maneira de explicar o pensamento das mulleres, mediante unha eterna dialéctica entre feminino e masculino. Cixous e Queizán establecen unha analoxía perfecta entre as mulleres e a palabra, mediante a cal ese Outro, que son as mulleres, se comprende e se aprende a si mesma. $\mathrm{O}$ acto de escribir faise desde as palabras en relación con ese feminino, ese Outro estranxeira dunha mesma. Pero, ¿como se escriben as mulleres, mulleres ás que non se ten acceso, que, ás veces, simplemente se adiviñan, nunha sociedade onde son disimuladas? ¿Como é, para Cixous e para Queizán, escribir a feminidade, participar na creación dunha memoria das mulleres, dunha escrita en femenino, nunha disciplina, a escrita, na que as mulleres están ausentes, como creadora ou como suxeito real?

Queremos coñecer tamén ata que punto Queizán se inspira do traballo de Mary Shelley, concretamente de Frankenstein, para entender a maternidade. Esta novela é a proba de que a Literatura constitúe unha disciplina que permitiu a transformación da realidade, ao establecerse como ponte entre a teoría e a práctica científica. Tomarei como guía da exposición o testemuño da autora e a construción ficcional de Donna Haraway sobre os límites entre o humano e o animal. Finalmente, analizarei como a ciencia ficción comenza a facerse máis realidade que nunca cando, nunha sociedade altamente tecnificada, o útero de cristal ou a placenta artificial nos fan pensar en formas de vida completamente diferentes ás que agora coñecemos e, talvez, as nais ou os corpos reprodutores sexan substituídos por máquinas e controlados polo poder científico e/ou contribúan á autonomía das mulleres, logrando así, di Queizán, a verdadeira igualdade. Dito doutro xeito, cando a Ciencia teña a capacidade de facer medrar un embrión humano fóra do útero materno, xa non existiría nada que diferenciase as mulleres dos homes, pois, quedarían liberadas da carga da maternidade.

\section{O CORPO TOMA A PALABRA}

As cuestións en torno ao feminino subxacen do feito de que, durante séculos, foi o home quen pensou e escribiu sobre as mulleres, non como ser humano semellante, senón como un ser diferente. Polo feito de que as mulleres posúen a facultade natural de procrear négaselles toda habilidade e toda intelixencia (Queizán 1998: 9). Os prototipos culturais de home e muller inclúen enfrontamentos dicotómicos que participaron no desprezo das mulleres ao longo da historia.

\section{Pasividade/actividade \\ Lúa/sol}

Natureza/Cultura ou mente, razón (...)

Corazón/cabeza

Sensible/intelixible

A través destas e outras oposicións descubrimos unha xerarquía (que eu invirto deliberadamente ao escribir para denunciala) na que o lado feminino é considerado o negativo. (Queizan 1995: 46)

Todas estas oposicións son sinaladas por Hélène Cixous e por María Xosé Queizán como fundamento do pensamento patriarcal. Ambas as dúas autoras destacan que tódalas dicotomías teñen como base as diferenzas xenéricas, como se a parella humana fose o modelo de organización de tódalas outras xerarquías da sociedade (Queizán 2006a: 117).

Corpo, palabra e sexo mestúranse (Queizán 2008: 6). De feito, na obra de Cixous, debemos definir as nocións de feminino e escritura como conceptos indisociables. O feminino, para Cixous, está na orixe da escritura. Segundo Queizán, o masculino apropiouse desa linguaxe: "a través dela, reforza a súa identidade e nega a identidade feminina" (2008: 6). A escrita das mulleres é, por tanto, crítica, creadora e ademais "in-corpora" (Queizán 1995: 54) os novos símbolos vinculados ás diferentes maneiras de ver o corpo feminino, unha nova relación co mundo, a vida e a lingua. "¿En que lugar do non ser vivimos as mulleres? (...) Os tempos son chegados de roubarlle o tempo aos deuses" (Queizán 1993b: 58). 
Dito doutro xeito, as mulleres expresa o que pensa co seu corpo. A feminidade na escrita pasa pola conquista da palabra, o simple feito de abrir a boca é xa unha transgresión (Cixous 1992: 54). "As mulleres viven en corpos calados, soñando" (1992: 58), sinala Hélène Cixous, e a perda do pudor representa unha subversión, xa que, "censurar o corpo é censurar, de paso, o alento, a palabra" (1992: 61 ), engade. Escribir significa tamén roubar a palabra, fuxir do silencio. É, di Queizán, o que deben pasar as mulleres, "convertidas en corpo, temos que partir del para encontrar o noso propio ser” (Queizán 1989: 81).

A escrita é unha chamada á sublevación e á non-sumisión a través da escritura, unha chamada á toma de conciencia, a tirar do fio (parafraseando a lenda da muller que agarda, a Penélope que tece), para que cada muller teza a súa propia tea, fóra desta tea de araña, esta "calceta razonable tecida por séculos sen ti", tecida sen a intervención das mulleres.

\section{ESCRIBO...}

Escribo para enxendrarme

-coma se fose outra-

no ovario do pensamento.

Para darme a luz

-e darme luz-

deslumbrada polas propias palabras.

Axúdoas a parir-se do meu corpo

¡tan miñas!

E tan outras.

Enfeitizada

míroas como á filla recén nacida

$\tan$ de $\min$

e tan descoñecida.

Fago as palabras co meu sangue e me asombran.

Falta que choren para que as

amamante. (Queizán 1993a: 39)

Se as mulleres, a través da escrita, poden dar a vida, iso tamén lle permite darse vida a si mesma, xa que a escrita é alimento:

L'amour qui pousse Cixous à écrire agit dans son corps, le peuple et le féconde. Cixous emploie souvent la métaphore de la maternité pour décrire la création littéraire. (Cremonese 1997: 30)

J'accouche. J'aime accoucher... Une envie de texte! Confusion!... Mes seins débordent ! Du lait. De l'encre. L'heure de la tétée. Et moi?
Moi aussi j'ai faim. Le goût de lait de l'encre ! (Cixous 1986: 40).

Segundo Queizán, só o home adulto posúe o Logos; é dicir, o pensamento e a linguaxe. En oposición, escribe os versos seguintes:

Quero inventar unha carne de palabras

(...) para eliminar o logos,

divisora do corpo e da linguaxe.

Acaba co privilexio de espírito sobre o corpo.

Non hai corpo sen palabras.

Non son o "continente oscuro"

(Queizán 1993a: 52)

Queizán escribe, especialmente nos seus poemas, sobre o corpo feminino como medio de avanzar cara a toma da palabra. Fisioloxicamente, a muller é unha femia e debe cumprir coas funcións que garanten o porvir da especie. Así, as mulleres, durante toda a súa vida, pero principalmente desde a puberdade ata a menopausa, vese na obriga de renunciar aos seus obxectivos individuais para servir á especie. Isto transforma o seu corpo en cárcere, da que sairá a través da liberación sexual. Por esta razón, a autora afirma que o corpo das mulleres é, ao mesmo tempo, o seu cárcere e a súa liberdade. Queizán comparte con Simone de Beauvoir a opinión sobre o corpo das mulleres como unha barreira, un obstáculo para acadar os seus obxectivos. Beauvoir ve como contratempos, as limitacións que o corpo lle impón ás mulleres, como grilletes á súa independencia (Beauvoir 1976: 50).

As mulleres son o produto do discurso dos outros, do discurso masculino (Queizán 2004: 83), que asocia a carne e o corpo á natureza, á terra e á pasividade (Queizán 1995:14). Queizán expresa no seu poema titulado "Antrotempo" que o corpo é "unha sublevación contra a memoria, contra as formas e os valores establecidos e tamén contra o autoodio" (González 1993: 542). O poemario Despertar das amantes é, como indica o seu título, un espertar, un renacer dunha nova muller que se pare a si mesma a través da palabra. Lembremos cando di "Escribo para enxendrarme" (1993a: 39).

A autora destece un a un os mitos patriarcais nos que as mulleres están encerrada, sen voz e sen acción, ou como lle chama Hélène 
Cixous, a muller está "frixidificada" (1992: 22), a muller está "conservada intacta de si mesma" (1992: 22), é un corpo simple, idealizado, creado polo poeta para unha muller namorada, imaxinaria, silenciosa e perfecta. En definitiva, una muller "exiliada da palabra" (Pena 1992: 79). Despertar das amantes é un paso cara á renovación da significación do amor, a configuración dun novo universo feminino, no que as mulleres son corpo e palabra, ou, máis ben, no que o corpo é palabra, a palabra das mulleres. Lembremos a expresión de Queizán de "amar é nomear", do poema "Palabras como fluxo", que Ana Acuña e Carmen Mejía consideran como un nacemento, un acto creador e un renacer da palabra (Acuña e Mejía Ruiz 1999: 11). Neste poemario, que será o primeiro dunha triloxía poética, María Xosé Queizán destece (Panero 1994: 103) as creacións principais dos poetas en materia de mulleres amadas "como destecendo o veo de Penélope" (1994: 103).

\author{
Metáfora da rebeldía \\ ¡POETA!, ¡mírame! \\ -se un día a amada erguera a rebeldía- \\ ¡Mírame! Os meus peitos non son analoxías. \\ Non son a túa máscara \\ non son isolda \\ non son a túa creación.
}

Desprendidas do colo as doas do adobío rolara polo chan a metáfora da metáfora. Esnaquizado o amor por sublime.

Mírame

rompe o espello

a miraxe onde me miras.

¡Ven!

Pégate ao meu corpo quente e real.

Fai do amor unha profanación.

(Queizán 1991a: 83)

Manuela Pena chámalle a esta toma de conciencia a "destrucción da metáfora" (1991a: 110), xa que, como ela ben explica, a metáfora é a arte de agochar a realidade, traéndoa a un plano irreal. Como consecuencia deste acto de rebelión, Manuela Pena destaca que quedan ao descuberto a falsidade e o engano poético. "A poesía destrúese para ser creada de novo", sinala. O corpo das mulleres é un produto de idealización continua na escrita masculina. A escrita feminista (é dicir, o retrato feminino ou de feminidade nos textos das escritoras feministas que fan unha escrita rebelde en torno ao corpo como manifestación da súa posición de xénero -especialmente a partir dos anos 1990, co nacemento do movemento denominado Poeróticas-) representa a pasaxe dunha aparición idealizada das mulleres (unha construcción mitificada dos poetas e escritores), a unha muller real (Rey 1983: 41).

O mito da muller salvaxe é un personaxe latente no imaxinario colectivo e é un pretexto para escribir o feminino. É o motor do acto de escribir, para falarlle ao Outro, que son as mulleres, para comprendela mellor ou falarse a si mesmas, como mulleres, para coñecerse me1lor. Escribir está na orixe da relación co feminino, con ese Outro extraño que descubrimos.

$\mathrm{O}$ camiño que Hélène Cixous percorre grazas á escrita correspóndese coa procura da feminidade evocada no descubrimento desta descoñecida, que son as propias mulleres para si mesmas. A autora nace da súa escrita e por tanto, do seu feminino:

C'était un chant! N'y a-t-il pas un rapport entre l'évocation, l'insufflation, ce parc vibrant (parcouru d'intensités complexes, de passions s'altérant, cherchant refuge) pépinière, et notre gestation? (de chants en peine de coeurs où se loger, de graines princières en quête de seins où piquer un somme, d'enfants kidnappés à revendre). (Cixous 1975: 35)

Trátase dunha escritura do feminino, pero tamén dunha escritura da feminidade. Pensemos por un instante na célebre frase de Simone de Beauvoir : "On ne naît pas femme, on le devient” (Beauvoir 1949: 285). Non esquezamos que Cixous naceu nesta época, durante este movemento do pensamento. $\mathrm{O}$ acceso á feminidade por parte do home parece imposible, mesmo que o home non poida comprender, intrinsecamente (o corpo inflúe no proceso das ideas), o que significa ser unha muller.

As mulleres "deben escribir unha poesía da verdade" (Rey 1983: 41). As escritoras perseguen posturas de rebelión necesarias, como as palabras da amada nos versos de "Metáfora da rebeldía", nas que a muller amada e consciente do que representa para o poeta, rebélase para 
recuperar o seu corpo e a súa identidade (Rey 1983: 41). As mulleres afástanse deste imaxinario dominante, que lles nega o estado de suxeitas e de produtoras de cultura, e polo cal unha muller é sinónimo do conxunto de valores xenéricos, no sentido biolóxico, que este termo implica; a muller é un ser "non existente, o negativo, o continente obscuro" (Queizán 1995:14).

A autora expresa no seu poema titulado "Antrotempo" o que significa "unha sublevación contra a memoria, contra as formas e os valores establecidos e tamén contra o autoodio" (González 1992: 542). O poemario é, como indica o seu título, un espertar, un renacer dunha nova muller que se pare a si mesma a través da palabra. Lembremos aquí algúns versos xa mencionados neste traballo.

"Páxina branca" (Queizán 1993a: 39) é unha homenaxe ao corpo das mulleres, á súa sexualidade. É así como di en "Palabras como fluxo": "Non deixes só ao corpo falar por ti, enche con palabras os gozos do silencio. Amar é nomear" (Queizán 1993a: 40). Dito doutro modo, fundir o corpo e a palabra constitúe un acto subversivo.

A través da escrita, Cixous busca un fin máis profundo e singular: descubrir o seu propio feminino, sobre a relación co feminino. Podemos sentilo na lectura de La Jeune née ou de Entre l'écriture: a relación co escrito vívese como unha relación carnal e especificamente feminina. Trátase de outorgarlle o seu lugar no mundo, que durante moito tempo rexeitou as mulleres e a creación dunha escrita de mulleres, nunha relación propia co mundo, separada da literatura masculina adquirida e recoñecida universalmente. Porén, cómpre que se inscriba nunha tradición literaria, para que a escrita feminina non sexa percibida como unha especie de caixón de xastre exótico e teña a súa lexitimidade.

Cixous utiliza imaxes físicas, que inclúen a boca e o gusto e en varias das súas obras utiliza a metáfora da alimentación para destacar a forza vital, nutritiva, indispensable da palabra e a escrita (Cremonese 1997: 30): "J'ai été élevée au lait des mots. Les langues m'ont alimentée (...) Si j'ai goûté, c'est la pâte du parler (...) Les textes je les mangeais, je les suçais, les tétais, les baisais. Je suis l'enfant innombrable de leur foule" (Cixous 1986: 40). E a través da escrita as mulleres escríbense, vívense. Muller e escrita son un.

Despois de ter sido pensada e nomeada, a experiencia individual devén unha realidade cun valor xeral e colectivo, é dicir, social e universal. Xa que simbolizar significa outorgar ao particular un valor arquetípico, no poema "Faime simbólica" (Queizán 1993a: 50) Queizán reclama facer do privado un exercicio modelo, devolverlle á carne a alegría e o poder revolucionario que as construcións masculinas lle rexeitaron. O poemario remata con "Metafísica", a nova metafísica que a autora propón está feita de carne e de ósos, componse do privado, nace dunha "terra a ras da terra" (Queizán 1993a: 48) e dun mundo onde a materia é o espírito; o corpo e o Logos fusiónanse nunha harmonía perfecta: "Sacar o corpo do saco da inmundicia/ onde nos meteran/ para elevar o corpo á metafísica" (1993a: 64).

As palabras escritas libéranse do corpo e permítenlle á autora, a escritora, a muller, vivir, liberarse do seu envoltorio, da súa condición. Cixous apunta en La Jeune Née, que a escrita debe pasar polo corpo; nace do corpo, nace na boca, como a voz, pero sen que a escrita e a palabra se opoñan. "On a plutôt la notion que l'écriture passe par tous les pores du corps, de ce «corps interdit», qu'elle passe par le goût, par le plaisir (...) Et ce n'est pas anodin qu'elle parle de «tous les pores du texte»" (Cremonese 1997: 22). O texto escribe e sente como un produto do corpo máis que da mente. Hélène Cixous ten, a través da escrita, acceso á liberdade, complexa para as mulleres:

Folles: celles qui sont obligées de re-faire acte de naissance tous les jours. Je pense: rien ne m'est donné. Je ne suis pas née une fois pour toutes. Ecrire, rêver, s'accoucher, être moi-même ma fille de chaque jour. Affirmation d'une force intérieure capable de regarder la vie sans mourir de peur, et surtout de se regarder soi-même, comme si tu étais à la fois l'autre -indispensable à l'amour- et rien de plus ni de moins que moi. (Cixous 1977: 16) 
A propia Cixous explica que se a escrita nace do corpo, este nacemento prodúcese dentro dun movemento de re-apropiación por parte das mulleres dese corpo que se lles foi prohibido e censurado durante séculos. As mulleres alíanse co coñecemento e a reivindicación das sensacións corporais exclusivamente femininas, xa sexa as sensacións da maternidade ou da sexualidade atopada-descuberta.

Helena González describe esta relación entre corpo e palabra como a "defensa da escrita como experiencia corpórea nacida da relación erótica entre palabra e corpo" (González 1993: 542). A triloxía poética de Queizán comezou con Metáfora da metáfora, onde a autora denuncia unha poesía masculina onde as mulleres pasaron de estar no silencio ou anulada como amante (Panero 1994: 103), limitada ao obxecto poético e a ser unha fantasía masculina, destinada a ser "a súa metáfora" (Fernández e Pardo 2003: 81); a namorada non é unha amante real, senón unha construción pura e simple do poeta: "AMANTE non es máis que palabras, as miñas" (Queizán 1991a: 8).

Neste poemario a autora busca desmitificar varias destas metáforas (Queizán 2003: 81) e remata cun acto de rebelión, que se reflicte na sede de romper a tea de araña, o velo mítico (Panero 1994: 103), o sudario. Podemos velo nos versos seguintes:

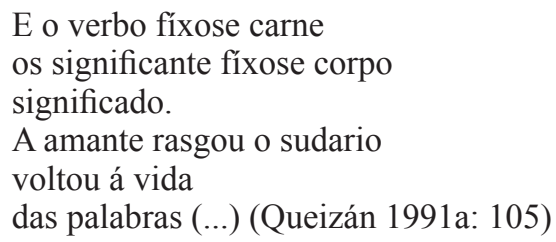

E o verbo fíxose carne os significante fíxose corpo significado.

A amante rasgou o sudario voltou á vida das palabras (...) (Queizán 1991a: 105)

Na construción do suxeito, o desexo xoga un rol importante. O erotismo e todo o que é relativo ao pracer sexual é, para Queizán, unha maneira de retirar o velo patriarcal (Queizan 1991b: 3). A represión sexual limitaba o acceso das mulleres á sexualidade, cuxo único obxectivo era a maternidade. A presenza do desexo e da construción dun 'suxeito feminino' sexuado, que nos amosa o sentir das mulleres, marca o camiño da liberdade, segundo Queizán. A sexualidade, di a autora, está socialmente construída e cómpre responder á idea esencialista do sexo (1993c: 45). Queizán explica que na sociedade patriarcal, "o desexo é patrimonio masculino. Ao feminino correspóndelle a pasividade" (1993: 45), e o acto sexual é tradicionalmente visto como o campo de batalla onde o macho exerce a súa supremacía sobre a femia.

Pero cando quen escribe é unha muller, éntrase nun mundo prohibido, entregada a unha vontade de transgredir o vetado, para manifestarse, para dicir o que non se di ou está mal dito polos homes. Ademais, antigamente prohibíase escribir ás mulleres, ao feminino, como lembra polo miúdo Hélène Cixous.

Alén da reapropiación do corpo, é dicir, logo de ter lexitimado e despois de espilo e facelo visible, Helena González emprega a palabra pornographie para definir unha actitude que consiste en que "as mulleres deciden exhibirse rebeldes" (González 2005: 31). Unha actitude producida por esta nova concepción do suxeito feminino e que, ademais de dotar dunha identidade este novo corpo feminino, superponse ás máximas do patriarcado (2005: 31).

O logos non deixa sentir o corpo.
Quero odiosa lei dos padres
Matar a Esfinge.
Non hai corpo sen palabras
grito.
nin misterio
nin secreto velado
velatorio
harén. a éxtase material.
Ser pensadora da terra.
A carne é leda e con ela
Escribirei moitos libros.
(Queizán 1993c: 52)

inventar unha carne de palabras para enterrar ao logos mortuorio

divisora do corpo e da linguaxe.

Acabar co privilexio do espírito sobre o corpo.

non son o "continente obscuro"

Non son perfume; son carne perfumada.

Reclamo a lucidez, o anuncio público,

As mulleres escritoras experimentan con frecuencia a escrita feminina como unha escrita culpable. A propia Cixous escribe de noite, 
como afirma en Les Rêveries de la Femme Sauvage: "Jadis je me sentais coupable de nuit" (Cixous 2003: 13).

No entanto, esta culpabilidade que todas as mulleres que escriben tratan de dominar e superar é, paradoxicamente, un motor incrible de creación. Esa culpa permítelles realizar novos exercicios literarios e deixarse levar por terreos sen explorar, prohibidos aos homes ou que simplemente non lles conveñen. As escritoras feministas, como Hélène Cixous, explotan esa culpabilidade que senten e fan caer todos os tabús.

Alén do corpo e das sensacións que pasan pola escrita, é a propia escrita que ten vida, que sae do corpo feminino. O espazo de creación feminina é diferente do dos homes. No caso da escritora, podemos falar dun espazo Interior por dúas razóns. $\mathrm{Na}$ escrita propiamente dita, tanto desde o punto de vista temático como estilístico, hai, como explica Béatrice Didier (1981: 10), o recurso dunha imaxinación diferente, a dos soños, a do corpo, asociado a unha dimensión cíclica que os homes non coñecen, o mal, por acceder desde o exterior. É concretamente a creación que se fai desde o Interior, desde o prohibido que mora nelas, as mulleres, que buscan espazos protexidos para entregarse ao acto de escribir: trátase do Interior da casa, e tamén da noite. Recorren a referencias persoais.

Este retorno ao Interior dunha mesma tamén pode facerse a través da ilusión. A propia Cixous describe o mundo dos soños como un mundo secreto, que rexe os seus pensamentos e a súa escrita:

Ils se narrent à moi dans leur langue, entre chat et loup, entre mêmes ou presque, entre douceur et cruauté, avant tout jour, avant toute heure. Je ne me réveille pas, le rêve me réveille d'une main, la main de rêve ouvre le tiroir à gauche de mon lit qui sert de coffre à rêves, saisit sans bruit le bloc de papier et le feutre pilot $\mathrm{V}$ signpen celui qui écrit si gros qu'il n'est pas besoin d'appuyer, il écrit tout seul, et l'on note dans le noir à toute allure, en marges, dedans pardessus bords, le récit remplit l'esquif à ras. Docile je ne dis mot le rêve dicte j'obéis les yeux fermés. J'ai appris cette docilité. Le rêve veut. Je fais. Je suis sans pensée sans réponse. (Cixous 2003: 11)
Este escribir desde o interior do que fala Cixous tamén subxace nun relato de Queizán "A bela adormecida na devesa" (2006b: 21), no que conflúe a paixón de Queizán, a través de Rosalía, pola escritura, a súa condición de mulleres precursoras, adiantadas ao seu tempo e incomprendidas, o seu amor pola lingua galega e o seu nacionalismo máis orgulloso e apaixoado. $\mathrm{O}$ conto describe o encontro entre Rosalía de Castro e a lingua galega (que é $A$ bela adormecida). Na época de Rosalía, no século XIX, escribir en galego non era doado. A lingua galega quedara reducida a un dialecto simple, desprezado e desacreditado, despois do período de ostracismo dos Séculos Escuros.

\section{MULLERES OU CORPO REPRODU- TOR?}

Vexamos agora como Mary Shelley influiu na obra e no pensamento de María Xosé Queizán. Á parte de polo feito de que Queizán titulou un dos seus últimos ensaios Mary Shelley e a súa criatura artificial (2011), esta autora inglesa tivo unha grande influencia no pensamento de Queizán no que respecta ao tema da maternidade, moitos anos antes da publicación deste ensaio.

A obra de Mary Shelley pode interpretarse desde varios puntos de vista. Durante moitos anos, a crítica interpretou a novela como unha denuncia da autora aos científicos, os que castigaba (castigábaos porque o experimento fracasou) por xogar a ser Deus. Pero o certo é que a novela tamén se pode abordar desde a perspectiva feminista como unha interesante expresión da autora polos seus medos ante a maternidade, ante a posibilidade de traer unha vida ao mundo, onde sobrevoa o risco do parto, o medo ao fillo imperfecto e ás responsabilidades que supón ser nai. A teoría feminista centrou boa parte das súas reflexións en cuestións referidas á ciencia e á maternidade, que supuxo unha reformulación do concepto de natureza, noción clave nas análises feministas desde os seus comezos.

Existe unha proposta de interpretación feminista da novela de Frankenstein, que se entende como un conxunto de relatos encubertos da propia vida de Mary Shelley. A primeira 
interpretación feminista de Frankenstein fíxoa Ellen Moers, en 1976. Así, aspectos da vida persoal de Shelley puideron ter influído na súa escritura. Primeiro, a profunda admiración que Shelley sentía por súa nai, Mary Wollstonecraft, autora de Vindicación dos dereitos da muller (1792), o que nos fai supoñer un pensamento feminista de base por parte da autora; en segundo lugar, a obsesión de Mary Shelley polo risco que corrían as mulleres ao dar a luz, que ademais morrían con frecuencia, moitas veces por infeccións provocadas polos propios médicos. A propia nai de Mary Shelley morreu uns días despois de dar a luz. Shelley ten un profundo sentimento de culpa pola morte de súa nai. Esa carga medra a medida que se fai adulta, porque seu pai tamén se encargou de alimentala (Moers 1985: 90). Cabería entón a posibilidade de que Mary Shelley puidese ter escrito Frankenstein con ese medo á maternidade e ao que supuña a maternidade na súa época, así como o perigo que implicaba para as mulleres, e para propor alternativas que permitisen traer novos seres vivos ao mundo sen a necesidade de arriscar a vida das mulleres.

Moers foi, ademais, unha das primeiras en dicir que a perda que sufriu Shelley dos seus fillos foi unha influencia crucial na creación de Frankenstein, e que Shelley escribiu esta novela para enfrontarse aos seus propios medos; niso influíu a súa propia experiencia como nai. O seu primeiro fillo nace prematuramente e morre. Shelley, deprimida, comeza a ter visións do bebé, o que os expertos chamarían hoxe en día un trastorno bipolar, despois dunha situación traumática como é a perda dese primeiro fillo. Perde dous fillos máis de curta idade e sofre un aborto. Iso fíxoa descubrir a impotencia que ocasiona a morte.

Moers di que a autora se preguntaba con frecuencia se era capaz de xerar vida ou soamente morte, e que a novela é un "mito do nacemento" (1985: 90) no que Shelley aborda temáticas como a súa culpabilidade por ter causado a morte de súa nai e por ter fallado ela mesma como nai. En palabras de Moers, Frankenstein é "un mito do nacemento que revela a súa repulsa cara á vida do acabado de nacer, o drama da culpa, o medo e todo aquilo que rodea o nacemento e as súas consecuencias" (1985: 90). E engade que Frankenstein é unha placenta sublimada a través da que Shelley expulsa a súa culpa, tanto por ter causado a morte de súa nai, como por non ter sido capaz de traer ao mundo un herdeiro e un fillo san para o seu marido (Moers 1985: 90).

Na obra de Queizán, podemos ver a preocupación polo tema da maternidade, en relatos como "Tolería por unha desmitificación" (1972), que conta a destrución dun laboratorio onde se tenta crear unha vida fóra do útero materno.

Seguramente, a ciencia, no futuro, substituirá o útero das mulleres e isto suporá unha auténtica liberación. Somos animais en vías de humanización e convén, en palabras de Ardrey "considerarmos á natureza como socias e non como escravas" e substituirá as condutas automáticas (entre as que se encontra enxendrar como mamíferas as criaturas que deus mande) pola evolución e a liberdade responsable. Pero, en xeral, e mesmo para as feministas, as técnicas reproductivas producen medo. (Queizán 1995: 52)

En Anti Natura Queizán critica as persoas que prefiren adaptarse ou someterse á natureza, en lugar de modificala (2008: 65). A autora cualifica esta actitude de afán por retroceder na evolución humana, que explica a súa indignación (2008: 66). Son, engade, os partidarios da medicina alternativa, das herbas fronte ás técnicas avanzadas da medicina moderna. "Mellor é deixalos coas súas prácticas de curación primitiva, a súa ignorancia sinxela que lles proporciona máis felicidade e lles trae menos problemas que a nós a instrución e o benestar social" (2008: 67), declara Queizán, xa que o naturalismo é unha idea conservadora en si mesma, que exclúe o compromiso coa vida e a política real (2008: 67). O retorno á lei natural e á crítica do progreso é o propio dos espíritos conservadores. Os avances técnicos non son malos en si mesmos. $\mathrm{O}$ que pode ser nefasto é o uso perverso que se fai deles (1995: 87). Por exemplo, utilizar as Novas Tecnoloxías Reprodutivas para coñecer o sexo do bebé e para escoller de preferencia o sexo masculino. É por iso, di a autora, que moitas feministas están contra os avances científicos, porque a 
xestión e a técnica están nas mans do poder patriarcal e as mulleres son utilizadas como cobaias, sometidas a probas longas e dolorosas, incómodas e degradantes, das que reciben previamente pouca información; e porque as mulleres están ausentes dos comités científicos e éticos onde se toman as decisións sobre este tipo de cuestións (Queizán 2008: 89). O feito de que Queizán lle chame liberación á substitución do útero feminino contrasta coa opinión que expresaba no seu conto "Tolería por unha desmitificación", en 1972, sobre a destrución dun laboratorio de natureza humana que un grupo de mulleres progresistas, do que a autora forma parte, segundo se deduce do texto, polo temor a que se poida crear e controlar a vida sen as mulleres.

Hoxe, a autora pensa que talvez as mulleres "debemos deixar de parir como os animais e a reprodución humana debe facerse nos laboratorios" (2008: 91). Deixarlle o camiño libre á fecundación in vitro, á fusión do óvulo e o espermatozoide, implantado despois na matriz das mulleres. Na seguridade, engade Queizán, de que axiña este proceso continuará nunha incubadora, con placentas artificiais, fóra do útero, fóra do corpo das mulleres, un proceso que xa existe no mundo animal, por exemplo, nas troitas de río (2008: 91). A autora asegura que a civilización consiste na emancipación da natureza, no paso da servidume tradicional á natureza a unha plena dominación dela. Queizán non entende o medo á manipulación do feto que escandaliza "as boas conciencias" (2008: 82), xa que hoxe esa manipulación fai posible ás nais-avoas e as nais-lesbianas, grazas aos ventres de aluguer:

Parece que xa chegou a hora de non confiar exclusivamente á natureza a formación das/ os novos seres. Aí están as Novas Tecnologías Reproductoras (NTR) para confirmalo. Parece que xa chegou a hora de que as mulleres se separen da natureza, das outras femias mamíferas e poidan dar vida social, vida legal. (Queizán 2008: 84)

A Ciencia, di a autora, permite a existencia das nais biolóxicas, as nais portadoras, nais de substitución, nais sentimentais; entre outras, e todas, di Queizán, fan posible "a nai simbólica" (1995, 84). Esta proliferación de nais é un antídoto contra a familia nuclear, que Queizán considera altamente prexudicial, sobre todo para o acabado de nacer, xa que crea unha dependencia, complexos e traumas. Para Queizán, a desacralización da nai e esta diversidade familiar é positiva. Os lazos biolóxicos son unha fonte de complexos e o que o acabado de nacer precisa é afecto e coidados. Esta cuestión biolóxica fica en segundo plano e non priva ao bebé de amor e tenrura, mesmo se os bebés non son froito dos nosos óvulos: "Esa minucia biolóxica perderá toda importancia" (Queizán 1995: 91). A grande emoción que se sente, di Queizán, despois de ter un fillo ou unha filla, non se atopa, para os humanos, no aspecto biolóxico, que non xustifica o amor e os coidados, senón no aspecto cultural (2008: 91). A maternidade, engade a autora, non ten nada de natural, porque a natureza non pode compararse coa educación dun novo ser humano, "dictar a conducta moral que implica un compromiso" (1999: 13).

A novidade en Frankenstein o el moderno Prometeo é que o monstruo é creado pola acción consciente do ser humano. Non é produto da man de Deus ou un fenómeno sobrenatural, senón que é un produto da ciencia. Víctor Frankenstein encarna a transgresión en dous sentidos: o primeiro é a condición do monstro como un ser construído a través da ciencia médica. En segundo lugar, é transgresor porque prescinde da figura feminina como corpo reprodutor e transforma o seu laboratorio nunha matriz virtual. Podería considerarse, e de feito así é, o monstro de Frankenstein como unha figura previa do cyborg. A diferenza é que o cyborg representa a perfección e Frankenstein é todo o contrario. O monstruo é rexeitado e repudiado; busca a aceptación, a integración, unha familia, a amizade, unha compañeira. $\mathrm{O}$ cyborg non precisa ningunha destas cousas. Representa a perfección do corpo a través da tecnoloxía. Respecto á comparación de ambas figuras, Donna Haraway escribe:

Unlike the hopes of Frankenstein's monster, the cyborg does not expect its father to save it through a restoration of the garden; that is, through the fabrication of a heterosexual mate, through its completion in a finished whole, a 
city and cosmos. The cyborg does not dream of community on the model of the organic family, this time without the oedipal project. The cyborg would not recognize the Garden of Eden; it is not made of mud and cannot dream of returning to dust ${ }^{1}$. (Haraway 1991: 151)

O cyborg non espera ningunha destas cousas e, dalgunha maneira, Shelley tamén reclama unha ruptura de todo o humano en Frankenstein. Moers di que a forza da novela está na forma en que se presenta como anormal ou como monstruoso todos os lazos que vencellan a pais e fillos. E iso é o mesmo que reclamar un cyborg, que é unha figura en parte humana, pero que está por riba do humano e por riba das emocións.

\section{CONCLUSIÓNS}

O percorrido da escrita feminista é, tanto para Queizán como para Cixous, a procura da feminidade; é unha escrita en feminino da feminidade. As mulleres buscan coñecerse a través desa escrita. Trátase de escribir o feminino, de deixalo falar.

Ademais, ao mesmo tempo, a escrita nace do feminino, dunha necesidade de describilo. E é unha busca individual. Cada autora vai na procura do seu propio feminino. O obxectivo é facerse cun lugar propio no mundo, para debullar as reflexións que se producen ao pasar de obxecta a suxeita, favorecendo a liberación do corpo feminino.

$O$ feito de que este traballo da escrita sexa individual fai que os camiños para definir o feminino sexan moi variados. Esa sensación de liberdade acadaríase seguindo a tendencia individualista do feminismo, que achega as mulleres á figura do cyborg e que supón a perfección por afastarse das emocións.

Para Queizán, a forma de acadar a auténtica igualdade pasa por ter como modelo a figura masculina, que entenderiamos como perfecta, por estar histórica e culturalmente máis preto da razón que da emoción, e polo que as mulleres deben renunciar a ese feminino asociado á maternidade para asemellarse a ese modelo a imitar que é o home.

Esta reflexión pode chegar a ser paradóxica, debido a que unha vez que se define o feminino e mais a feminidade a través da escrita das propias mulleres, Queizán proporía destruír ese feminino, para crear outro tipo de mulleres semellantes aos homes; dito doutro xeito, significaría renunciar á esencia do feminino para imitar o masculino.

\section{REFERENCIAS BIBLIOGRÁFICAS}

AcuÑA, Ana e Carmen MejíA RuIz (1999): “O amor na obra de María Xosé Queizán”, Madrygal. Revista de Estudios Gallegos 2, pp. 11-20.

Beauvorr, Simone de (1976 [1949]): Le Deuxième Sexe I. Paris: Gallimard.

Blanco, Carmen (1986): "Galicia e a muller en Amantia”, Festa da palabra silenciada 3, pp. 25-28.

Broncano, Fernando e David Hernández de la Fuente (eds.) (2012): De Prometeo a Frankenstein. Autómatas, cyborgs y otras creaciones más que humanas. Barcelona: Evohé Didaska.

Cixous, Hélène (1975): Souffles. Paris: éd. Des Femmes.

(1986): Entre l'écriture, en Entre l'écriture. Paris: éd. Des femmes.

${ }^{1}$ A diferenza da esperanza do monstro de Frankenstein, o cyborg non espera que seu pai o salve por medio dunha restauración do xardín; é dicir, a través da fabricación dunha parella heterosexual, a través da súa culminación nun todo acabado, unha cidade e un cosmos. O cyborg non soña co modelo da familia biolóxica, esta vez sen o complexo de Edipo. O cyborg non recoñecería o Xardín do Edén, non está feito de barro e non pode soñar con volver ao po. 
(1992): Le rire de la méduse. Paris: Éd. Des femmes.

(2000): Les Rêveries de la femme sauvage, scènes primitives. Paris: Galilée.

(2003): Rêve je te dis. Paris: Galilée.

Cixous, Hélène e Catherine Clement (1975): La Jeune Née. Paris: U. G. E, 10/18.

Cixous, Hélène, Madeleine Gagnon e Leclerc Annie (1977): La Venue à l'écriture. Paris: U. G. E, $10 / 18$.

Cremonese, Laura (1997): Dialectique du masculin et du féminin dans l'oeuvre d'Hélène Cixous. Paris: Didier erudition.

DiDIER, Béatrice (1981): L'écriure-femme. Paris: PUF.

Fernández García, María Jesús e María X. Pardo Fernández (coord.) (2003): “A literatura da transgresión", en M. X. Queizán, Textos de Mulher/Muller/Mujer. Cáceres: Universidad de Extremadura, pp. 81-92.

GonzÁlez, Helena (1993): “A subversión ó servizo da outredade”, Grial. Revista galega de cultura 120 , pp. 542-543.

(2005): Elas e o paraugas totalizador. Escritoras, xénero e nación. Vigo: Xerais.

Haraway, Donna (1991): Simians, Cyborgs and Women: The Reinvention of Nature. Nova York / Londres: Routledge / Free Association Books.

Moers, Ellen (1985): Literary Women: The Great Writers. Oxford: Oxford University Press, pp. 90-98.

PANero, Carmen (1994): “Despertar das amantes de María Xosé Queizán”, Festa da palabra silenciada 10, pp. 103-104.

Pena Santiago, Manuela (1991): "Metáfora da metáfora ou a destrucción da metáfora", Festa da palabra silenciada 8, pp. 110-112.

— (1992): "Fóra de min", Festa da palabra silenciada 9, pp. 79-80.

QueIzÁn, María Xosé (1989): Evidencias. Vigo: Xerais.

(1991a): Metáfora da metáfora. A Coruña: Espiral Maior.

- (1991b): “Introducción”, Festa da palabra silenciada 8, p. 3.

- (1993a): Despertar das amantes. A Coruña: Espiral Maior.

(1993b): "Roubar o tempo", en Mª X. Queizán, Despertar das amantes. A Coruña: Espiral Maior, p. 58.

(1993c): "O desexo: Un discurso entre o amor e a morte", en El deseo. La construcción del sujeto femenino. Conferencias. (A Coruña, Febrero/marzo de 1993). A Coruña: Ediciones Fundación Paideia (colección Fundación Paideia, Documentos 2), pp. 45-54.

(1995): Escrita da certeza. Por un feminismo optimista. A Coruña: Espiral Maior.

(1998): Misoxinia e racismo na poesía de Pondal. Santiago de Compostela: Laiovento.

(1999): "Madres sen destino", Festa da palabra silenciada 15, pp. 13-16.

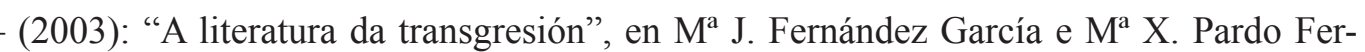
nández (coords.), Textos de Mulher/Muller/Mujer. Cáceres: Universidad de Extremadura, pp. $81-92$. 
(2004): Racionalismo politico e literario. Conciliar as ciencias e as humanidades. Vigo: Xerais.

(2006a): “Centenario de Hanna Arendt, feminista sen querer", Festa da palabra silenciada 22, pp. 117-120.

(2006b): "A bela adormecida na devesa", en Contos de colonias escolares, belas adormecidas, atentados e tiburóns. Santiago de Compostela: Xunta de Galicia, pp. 21-33.

(2008): “O verbo patriarcal”, Festa da palabra silenciada 24, pp. 6-10.

Rey, Pierre-Louis (1983): “Femme réelle ou apparition?”, en L'éducation sentimentale de Flaubert. Paris: Hatier, p. 41.

SHELley, Mary (1999): Frankenstein o el moderno Prometeo. Madrid: Unidad Editorial. 